\title{
Polymorphic Analysis and Genetic Similarity of Genus Ficus L. (Moraceae) in Egypt
}

\author{
M.E. Tantawy' ${ }^{1}$ T.R. Mohamed ${ }^{2}$, S.S. Teleb ${ }^{3}$ and R.M. \\ Salah-El-din ${ }^{2}$ \\ ${ }^{1}$ Botany Department, Faculty of Science, ${ }^{2}$ Botany Department, \\ University College for Women's (Arts, Science \& Education), \\ Ain Shams University Cairo and ${ }^{3}$ Botany Department, Faculty \\ of Science, Zagazig University, Zagazig, Egypt.
}

\begin{abstract}
N INTEEN SPECIES belonging to genus Ficus were obtained from three Egyptian gardens to study the information derived from ISSR fingerprinting, and to estimate the level of polymorphism and genetic similarity. Five ISSR primers were used to estimate the level of polymorphism among the different species. This study indicates that, the total number of bands detected by the different ISSR primers was 229 all of them were polymorphic, representing a level of polymorphism of $100 \%$ and an average number of 46 polymorphic bands per primer. The ISSR analysis revealed the highest genetic similarity $(85 \%)$ between $F$. afzelii and $F$. benghalensis, while the lowest genetic similarity (58\%) was observed between $F$. carica and $F$. sycomorus. The obtained results clearly revealed a high level of similarity among the investigated Ficus species, ensuring the highest degree of homology and the narrow genetic background of these species. The two studied taxa of subgenus Ficus, viz., F. carica and $F$. deltoidea were widely separated and showed relations with the taxa of subgenus Urostigma. Also, the three studied taxa of subgenus Sycomorus possessed relations with members of subgenus Urostigma.
\end{abstract}

Keywords: Ficus, ISSR, Polymorphism, Fingerprinting.

Ficus L. (Moraceae) constitutes one of the largest genera of angiosperms (Frodin, 2004), consisting of about 1000 species from pantropical, subtropical origins, several of which are desirable interior foliage plants. Ficus includes a large number of indoor ornamental plants and garden and roadside trees (Wagner et al., 1999), and formed a distinctive monophyletic clade within the family (Judd et al., 1999). The classification of Ficus emphasized on two items; the first is whether the species is monoecious or functionally dioecious (gynodioecious), the second is on the tight coevolutionary relationship that exists between Ficus species and their specific wasp pollinators (Weiblen, 2000). One of the most widely adopted infrageneric classification of Ficus is that of Corner (1965). In that classification, Ficus is divided into four subgenera (Urostigma, Pharmacosycea, Sycomorus and Ficus), with the functionally dioecious species united under the subgenus Ficus. Yet, in the most recent classification by Berg and Corner (2005), Ficus is divided into six subgenera and a number of sections. Several DNA-markers (RAPD, RFLP, SSR, and ISSR) have available to identify the varieties / accessions. These markers can be effectively used to answer the phylogenetic 
relationship between Ficus accessions (Chatti et al., 2007). Inter simple sequence repeat (ISSR) overcomes many of the limitations faced by different marker system and has a higher reproducibility (Guasmi et al., 2006). For instance ISSR markers may offer considerable variation among varieties and have been widely used in cultivated species (Wolfe and Liston, 1998). ISSR has been described as a powerful technique to assess genetic diversity among closely related species and to detect similarities between and within plant species levels (Ghariani et al., 2003). The optimal utilization of diversity ISSR-PCR has been used widely in plants for the analysis of genetic relationships between and within species (Martin and Yelamo, 2000), assessment of hybridization in natural populations (Wolfe et al., $1998 \mathrm{a \& b}$ ) and germplasm analysis (Gillbert et al., 1999). Further, ISSR-PCR is useful in fingerprinting and characterization of accessions (McGregor et al., 2000) and identification of cultivars and varieties (Kumar et al., 2001). Occasionally, it has been used to study relationships at the interspecific level (Huang and Sun, 2000).

Salhi-Hannachi et al (2005) compared the genetic diversity in two Tunisian fig cultivars by using RAPD and ISSR markers. As Ficus species are represented by a large number of varieties / accessions which are facing genetic erosion. Rout and Aparajita (2009) proved that clear cut separation of the 23 Ficus accessions and were in broad agreement with the morphology. Both molecular and morphological markers will be useful for preservation of the Ficus germplasm. They demonstrated that information for accession identification and the presence of accessions in the natural distribution of parental species for Ficus have been confirmed with ISSR markers. This analysis is quick and reproducible, can generate sufficient polymorphism to identify the Ficus accessions, although most ISSR alleles are dominant rather than co-dominant. Using some of the co-dominant markers like SSR can further check the findings.

Nabil and Abou-Ellail (2013) proved that RAPD markers are useful for germplasm discrimination as well as for investigation of patterns of variation in seven Fig (Ficus carica) cultivars. These results indicated that RAPD is useful, rapid and accurate technique for studying genetic diversity and germplasm characterization of Ficus carica some cultivars. There is a wide spectrum genetic variation among studied fig varieties, these variation could be an effective factor in breeding program.

The main objectives of the present study are; study the taxonomic information through the investigation of DNA cretiria, compare and bind out the relationships between the studied species on the bases of DNA fingerprint using ISSR-PCR analysis, estimate the level of polymorphism and genetic similarity and identify some moleculer genetic markers which help in identification of the taxa under investigation. 


\section{Material and Methods}

The studied nineteen Ficus species are outlined in the following Table:

TABLE 1. Data collection.

\begin{tabular}{|c|c|c|c|}
\hline No & Species & Subgenus & Source \\
\hline 1 & $\begin{array}{l}\text { Ficus afzelii G. Don., In J. C. Loudon, Hort. Brit. ed. 1: } 416.1830=F \text {. } \\
\text { saussureana DC. }\end{array}$ & Urostigma & OBG \\
\hline 2 & F. benghalensis L. in Sp. Pl. 2: 1059. $1753=F$. indica L. & Urostigma & OBG \\
\hline 3 & $\begin{array}{l}\text { F. benjamina var. comosa (Roxb.) Kurz, In Forest Fl. Burma 2: } \\
\text { 446. } 1877 .\end{array}$ & Urostigma & AG \\
\hline 4 & $\begin{array}{l}\text { F. carica L. In Sp. Pl. 2: 1059. } 1753=F \text {. carica L. var. rupestris } \\
\text { Hausskn }\end{array}$ & Ficus & AG \\
\hline 5 & $\begin{array}{l}\text { F. cordata Thumb. subsp. salicifolia }(\text { Vahl })=F \text {. salicifolia } \text { Vahl, In } \\
\text { Symb. Bot. 1: } 82.1790 .\end{array}$ & Urostigma & AG \\
\hline 6 & $\begin{array}{l}\text { F. cunninghamii Miq., In Ann. Mus. Bot. Lugd. Bat. iii, 286- } \\
\text { Austral. }\end{array}$ & Urostigma & OBG \\
\hline 7 & $\begin{array}{l}\text { F. deltoidea Jack, In Malayan Misc. 2(7):71.1822. =F. diversifolia } \\
\text { Blume }\end{array}$ & Ficus & AG \\
\hline 8 & $\begin{array}{l}\text { F. elastica Roxb. ex Hornem, In Hort. Bot. Hahn. Suppl. } 7.1819= \\
\text { F. decora Hort. }\end{array}$ & Urostigma & AG \\
\hline 9 & $\begin{array}{l}\text { F. infectoria Roxb., In Ann. Bot. Gard. Calcutta, i.l.t. 75, 84(1887). } \\
=F \text {. virens Aiton }\end{array}$ & Urostigma & ZG \\
\hline 10 & $\begin{array}{l}\text { F. laurifolia } \text { Hort. ex. Lam., In Encycl. Meth. (Bot.) } 2: 495.1786 .= \\
F . \text { inspida } \text { wika }=F \text {. glabrata } \text { H. B. K.=F. anthelemintica Mart. }\end{array}$ & Urostigma & ZG \\
\hline 11 & $\begin{array}{l}\text { F. macrophylla Desf. ex Pers., In Syn. Pl. 2: 609. } 1807=F \text {. } \\
\text { magnolioides Borzi }\end{array}$ & Urostigma & OBG \\
\hline 12 & $\begin{array}{l}\text { Ficus mysorensis B.Heyne ex Roth, In J. J. Roemer \& J. A. } \\
\text { Schultes, Syst. Veg. 1:508.1817( A. W. Roth, Nov. Pl. Sp. } 390.182 \\
=\text { F. drupacea } \text { var. pubescens (Roth.) corer }\end{array}$ & Urostigma & OBG \\
\hline 13 & $\begin{array}{l}\text { F. palmata Forsk. }=F \text {. pseudosycomorus Decne., In Ann. Sc. Nat. } \\
\text { Ser. II.ii. (1834) } 242 .\end{array}$ & Sycomorus & OBG \\
\hline 14 & $\begin{array}{l}\text { F. platypoda (Miq.) A. Cunn. ex Miq., In, Ann. Mus. Bot. } \\
\text { Lugduno-Batavum 3: } 287.1867=\text { Urostigma platipodum }\end{array}$ & Urostigma & OBG \\
\hline 15 & $\begin{array}{l}\text { F. racemosa Wall-Cat. } 1799=F . \text { glomorata Roxb., In } \mathrm{Pl} . \\
\text { Coromandel 2: } 13, \text { t. } 123 .\end{array}$ & Sycomorus & OBG \\
\hline 16 & F. religiosa L., In Sp. Pl. 2:1059. 1753 & Urostigma & AG \\
\hline 17 & F. retusa L. $=$ F. nitida Thunb. In Ficus 10.1786. & Urostigma & AG \\
\hline 18 & $\begin{array}{l}\text { F. spragueana Mildbr. \& Burret, In, Bot. Jahrb. Syst. 46: } 253 . \\
1911 .\end{array}$ & Urostigma & OBG \\
\hline 19 & F. sycomorus L., In Sp. Pl. 1059. 1753. & Sycomorus & OBG \\
\hline
\end{tabular}

Author citation and synonymy were verified according to $\mathrm{W}^{3}$ TROPICOS (2008), GRIN(2008) and IPNI (2008). OBG=Orman Botanical Garden, Ministry of Agriculture, Dokky, Giza, Egypt, AG=Botanical Garden of Ain Shams University, Faculty of Science, Abbasia, Cairo, Egypt, ZG=Zoo-Garden, Dokky, Giza, Egypt. 
Extraction and purification of genomic DNA

The genome DNA of studied species was extracted using CTAB (hexadecyl trimethyl ammonium bromide) assay as described by Porebski et al. (1997).

\section{Inter Simple Sequence Repeats (ISSRs)}

ISSR markers involve PCR amplification of DNA using a single primer composed of microsatellite sequence Primer Code IS3, IS4, IS6, IS10 and A9 (Bioneer, sequencing service Daedeok-gu, Daezeon 306-220, South Korea) such as (CA)7 anchored at the $3^{\prime}$ or 5 end by 2-4 arbitrary, often degenerate nucleotides. The sequences of repeats and anchored nucleotides were randomly selected. The technique was carried out according to Adawy et al. (2002 and 2004a). Five oligonucleotides composed wholly of defined, short tandem repeat sequences with anchor, and representing different microsatellites (di- and trirepeats) were used as generic primers in PCR amplification of inter simple sequence repeat regions. Oligonucleotide primers to microsatellite repeats (Table 2) were synthesized on an ABI 392 DNA/RNA synthesizer at Agricultural Genetic Engineering Research Institute (AGERI), ARC, Giza, Egypt.

TABLE 2. Name and sequence of the primers used in ISSR detection.

\begin{tabular}{|c|c|}
\hline Primer Code & Sequence ( 5 - 3 $)$ \\
\hline IS3 & TTT(TCC) 5 \\
\hline IS4 & CAT(CA) ${ }_{7}$ T \\
\hline IS6 & $(\mathrm{GA})_{8} \mathrm{CG}$ \\
\hline IS10 & $(\mathrm{TCC})_{5} \mathrm{AC}$ \\
\hline A9 & $(\mathrm{AGC})_{4} \mathrm{AC}$ \\
\hline
\end{tabular}

ISSR-PCR reaction and thermo-cycling profile

PCR was performed in $25 \mu \mathrm{l}$ reaction volume containing $1 \mathrm{X}$ PCR buffer, $1.75 \mathrm{mM} \mathrm{MgCl} 2,5 \mathrm{mM}$ of each dNTPs, $40 \mathrm{pM}$ oligonucleotide primer, $25 \mathrm{ng}$ genomic DNA and one unit of Taq DNA polymerase. The PCR amplification conditions were performed as follows: (1) an initial denaturation step at $94^{\circ} \mathrm{C}$ for $30 \mathrm{sec}, 65^{\circ} \mathrm{C}$ for $45 \mathrm{sec}$ and $72^{\circ} \mathrm{C}$ for $1 \mathrm{~min}$, (2) the annealing temperature was lowered each cycle $1^{\circ} \mathrm{C}$ during nine cycles, which gave a touch down phase of ten cycles, (3) thirty-five cycles performed at $94^{\circ} \mathrm{C}$ for $30 \mathrm{sec}, 55^{\circ} \mathrm{C}$ for $45 \mathrm{sec}$. and $72^{\circ} \mathrm{C}$ for $1 \mathrm{~min}$, and an extension cycle at $72^{\circ} \mathrm{C}$, (4) the PCR products were separated on $1.5 \%$ agarose gel in $1 \mathrm{X}$ TBE buffer containing ethidium bromide and photographed with a Polaroid camera.

\section{Data analysis}

The banding patterns generated by ISSR markers were used to determine the genetic relatedness of 19 Ficus species. Clear and distinct amplification products were scored as (1) for presence and (0) for absence of the developed bands. The similarity coefficient between two genotypes was estimated according to Jaccard's coefficient (Jaccard, 1908). 
Jaccard's formula: $\mathrm{GS}=\mathrm{N}_{\mathrm{AB}} /\left(\mathrm{N}_{\mathrm{AB}}+\mathrm{N}_{\mathrm{A}}+\mathrm{N}_{\mathrm{B}}\right)$, where

GS: is the measure of genetic similarity between two samples

$\mathbf{N}_{\mathbf{A B}}$ : is the number of bands shared by $\mathrm{A}$ and $\mathrm{B}$,

$\mathbf{N}_{\mathrm{A}}$ : is the number of bands present in sample $\mathrm{A}$,

$\mathbf{N}_{\mathbf{B}}$ : is the number of bands present in sample B.

The similarity matrix was used in the cluster analysis by using the NTSYS-pc software version 2.02 (Exeter Software, NY, USA; Rohlf, 1998), where the SIMQUAL program was used to calculate Jaccard's coefficients. The cluster analysis was employed to organize the observed data into meaningful structures to develop taxonomies. At the first step, when each species represents its own cluster, the distance between these species are defined by the chosen distance measure (Jaccard's coefficient). However, once several species have been linked together, the distance between two clusters is calculated as the average distance between all pairs of species in the two different clusters. This method is called Unweighted Pair Group Method using Arithmatic Average (UPGMA) using Sequential Agglomerative, Hierarchical and Nested cluster (SAHN) (Sneath and Sokal, 1973).

\section{Results and Discussion}

\section{ISSR diversity as revealed by ISSR markers}

The studied species were analyzed using five Inter Simple Sequence Repeat (ISSR) primers. These primers were anchored either at the $5^{`}$ end or at the 3 end or at both ends. The amplification results of the ISSR primers used in this investigation are presented in (Table 2). The five primers including two dinucleotide repeat and three tri-nucleotide repeat produced good reproducible and scorable patterns and the amplification profiles were screened for the presence of polymorphisms among the studied nineteen Ficus species (Fig. 1. A-E).

As shown in (Table 3), a total of 229 fragments were generated by the five primers with an average of 46 fragments / primer. Trinuceotide 3' anchored primer IS10 yielded the highest number of products (52 fragments), while trinucleotide $5^{\prime}$ anchored primer IS3 detected the lowest number of products (36 fragments). On average, one primer was amplified 46 fragments. The numbers of polymorphic bands were 229 with $100 \%$ of polymorphism. Moreover, the size of the amplified fragments varied with different primers, ranging from 2402 to 175 bp. Among different species, $F$. platypoda showed the highest number of polymorphic bands (62), whereas $F$. benghalensis showed the lowest number of polymorphic bands (31).

\section{Genetic relationships as revealed by DNA marker}

Detection of genetic variation and determination of genetic relationships between species is an important consideration for the efficient conservation and utilization of plant genetic resources. Once the morphological traits or the generated molecular marker profiles have been evaluated, there are different strategies to estimate the similarity between the analyzed individuals. Similarity indices measure the amount of closeness between two species, the larger the value the more similar are the two species. 


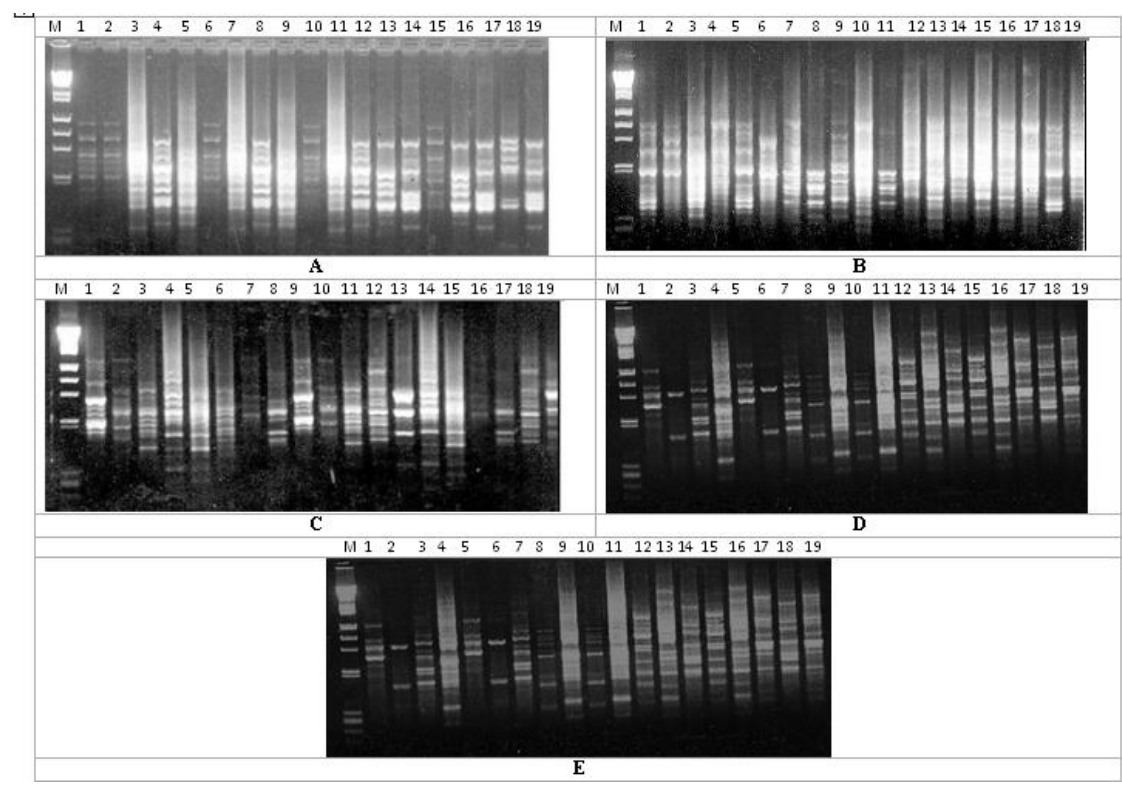

Fig. 1. ISSR profiles obtained by different primers on the studied 19 Ficus species A:IS3, B: IS4, C: IS6, D: IS10 and E: A9.

TABLE 3. Total number of bands, polymorphic bands, species-specific bands and percentage of polymorphism revealed by ISSR markers among the studied Ficus species.

\begin{tabular}{|c|c|c|c|c|c|c|}
\hline Primer & sequence & $\begin{array}{c}\text { Length of } \\
\text { amplification } \\
\text { product (bp) }\end{array}$ & $\begin{array}{l}\text { No. of } \\
\text { bands }\end{array}$ & $\begin{array}{l}\text { Unique } \\
\text { bands }\end{array}$ & $\begin{array}{l}\text { Polymorphic } \\
\text { bands }\end{array}$ & $\begin{array}{c}\text { Species- } \\
\text { specific } \\
\text { percentage } \\
\text { for primer }\end{array}$ \\
\hline IS3 & TTT(TCC) & 1340-211 & 36 & 10 & 36 & 27.8 \\
\hline IS4 & $\mathbf{C A T}(\mathbf{C A})_{7} \mathbf{T}$ & 1768-221 & 44 & 8 & 44 & 18.18 \\
\hline IS6 & $(\mathrm{GA})_{8} \mathrm{CG}$ & 1845-175 & 49 & 8 & 49 & 16.32 \\
\hline IS10 & $(\mathrm{TCC})_{5} \mathrm{AC}$ & 2402-196 & 52 & 15 & 52 & 28.8 \\
\hline A9 & $(\mathrm{AGC})_{4} \mathrm{AC}$ & 1462-193 & 84 & 14 & 48 & 29.1 \\
\hline \multicolumn{3}{|l|}{ Total } & 229 & 55 & 229 & \\
\hline \multicolumn{3}{|l|}{ Mean } & 46 & 11 & 46 & \\
\hline \multicolumn{3}{|c|}{ Percentage } & & & 100 & 24.04 \\
\hline
\end{tabular}

Genetic relationships as revealed by ISSR markers

The scored data obtained from five primers were used to determine the genetic similarity among the studied species using Jaccard's coefficient (Table 4). The highest similarity percentage $(85 \%)$ was observed between $F$. afzelii and $F$. benghalensis. This was followed by genetic similarity of $(81.7 \%)$ between $F$. benghalensis and $F$. deltoidea. F. infectoria, F. laurifolia, F. benjamina v comosa and $F$. cunninghamii have genetic similarity (80\%). F. elastica and F. macrophylla have genetic similarity (77\%). Also, $F$. carica and $F$. cunninghamii have the same genetic similarity. The lowest genetic similarity (58\%) was detected between $F$. carica and $F$. sycomorus. 
In the present study, five ISSR primers were used for fingerprinting, estimating genetic diversity and relationships of Ficus species. By using these primers, 229 discernible DNA fragments were generated with 229 polymorphic ones. The present study revealed quite high polymorphism (100\%). The high percentage of polymorphism is common for ISSR amplified products. Prevost and Wilkinson (1999), Hess et al. (2000) and Manimekalai and Nagarajan (2006) obtained similar results in Potato 90\%, Olea europaea, 100\%, and Cocos nucifera 77.4\%.

The variation of the polymorphism in the different species can be explained by the hypothesis that the microsatellites, whose sequences are complementary to the primer, were abundant or rare in the genome of the studied species, these microsatellites occupied some sites sufficiently distant not allowing the synthesis of sequences that separating them (Guasmi et al., 2006).

TABLE 4. Genetic similarity matrices among Ficusspecies as computed according to Jaccard's Coefficient.

\begin{tabular}{|c|c|c|c|c|c|c|c|c|c|c|c|c|c|c|c|c|c|c|c|}
\hline & 1 & 2 & 3 & 4 & 5 & 6 & 7 & 8 & 9 & 10 & 11 & 12 & 13 & 14 & 15 & 16 & 17 & 18 & 19 \\
\hline 1 & 1.000 & & & & & & & & & & & & & & & & & & \\
\hline 2 & 0.852 & 1.000 & & & & & & & & & & & & & & & & & \\
\hline 3 & 0.751 & 0.742 & 1.000 & & & & & & & & & & & & & & & & \\
\hline 4 & 0.721 & 0.712 & 0.742 & 1.000 & & & & & & & & & & & & & & & \\
\hline 5 & 0.742 & 0.786 & 0.808 & 0.777 & 1.000 & & & & & & & & & & & & & & \\
\hline 6 & 0.747 & 0.817 & 0.734 & 0.712 & 0.760 & 1.000 & & & & & & & & & & & & & \\
\hline 7 & 0.734 & 0.769 & 0.694 & 0.672 & 0.712 & 0.725 & 1.000 & & & & & & & & & & & & \\
\hline 8 & 0.734 & 0.803 & 0.677 & 0.664 & 0.712 & 0.716 & 0.764 & 1.000 & & & & & & & & & & & \\
\hline 9 & 0.734 & 0.769 & 0.703 & 0.655 & 0.729 & 0.681 & 0.729 & 0.808 & 1.000 & & & & & & & & & & \\
\hline 10 & 0.742 & 0.786 & 0.703 & 0.672 & 0.712 & 0.760 & 0.773 & 0.755 & 0.755 & 1.000 & & & & & & & & & \\
\hline 11 & 0.686 & 0.729 & 0.681 & 0.659 & 0.707 & 0.721 & 0.707 & 0.751 & 0.690 & 0.742 & 1.000 & & & & & & & & \\
\hline 12 & 0.655 & 0.699 & 0.659 & 0.594 & 0.659 & 0.655 & 0.651 & 0.712 & 0.659 & 0.686 & 0.664 & 1.000 & & & & & & & \\
\hline 13 & 0.694 & 0.677 & 0.664 & 0.616 & 0.646 & 0.668 & 0.664 & 0.690 & 0.672 & 0.690 & 0.633 & 0.664 & 1.000 & & & & & & \\
\hline 14 & 0.694 & 0.721 & 0.664 & 0.616 & 0.681 & 0.703 & 0.638 & 0.707 & 0.699 & 0.716 & 0.694 & 0.638 & 0.677 & 1.000 & & & & & \\
\hline 15 & 0.721 & 0.747 & 0.681 & 0.642 & 0.707 & 0.747 & 0.707 & 0.742 & 0.699 & 0.734 & 0.721 & 0.716 & 0.677 & 0.747 & 1.000 & & & & \\
\hline 16 & 0.694 & 0.738 & 0.646 & 0.616 & 0.672 & 0.686 & 0.716 & 0.699 & 0.725 & 0.734 & 0.642 & 0.655 & 0.712 & 0.651 & 0.668 & 1.000 & & & \\
\hline 17 & 0.725 & 0.742 & 0.642 & 0.664 & 0.677 & 0.716 & 0.703 & 0.747 & 0.729 & 0.729 & 0.655 & 0.659 & 0.672 & 0.734 & 0.734 & 0.707 & 1.000 & & \\
\hline 18 & 0.747 & 0.764 & 0.672 & 0.624 & 0.699 & 0.738 & 0.681 & 0.681 & 0.672 & 0.716 & 0.721 & 0.664 & 0.633 & 0.712 & 0.721 & 0.677 & 0.681 & 1.000 & \\
\hline 19 & 0.646 & 0.690 & 0.598 & 0.585 & 0.651 & 0.646 & 0.616 & 0.651 & 0.624 & 0.712 & 0.690 & 0.633 & 0.629 & 0.699 & 0.672 & 0.655 & 0.712 & 0.672 & 1.000 \\
\hline
\end{tabular}


ISSR primers based on di-nucleotide repeats reveal high polymorphism (Nagaoka and Ogihara, 1997; Blair et al., 1999, Joshi et al., 2000 and He et al., 2009). In this study, ISSR markers revealed high levels of polymorphism with an average of 46 polymorphic bands per primer. At the same time, ISSR primers based on di-nucleotide repeats generated more polymorphic bands than those based on tri-nucleotide 5 anchored repeats but tri-nucleotide 3' anchord repeats generated the highest numbers of polymorphic bands. According to ISSR results, the most closely related species were $F$. afzelii and $F$. benghalensis with the highest similarity index (0.85). On the other hand, the most distantly related species were $F$. carica and $F$. sycomorus with low similarity index (0.58). Danuta et al. (2006) and Heikal et al. (2008) proved that ISSR is a good tool to assess the genetic similarity and relationships between species.

\section{Unique markers as revealed by ISSR}

Unique markers (species-specific markers) were identified, which could easily discriminate between the studied species. Unique markers are defined as bands that are present or absent and specifically identify samples from the others. The bands that present in a sample but not found in the others are termed positive unique markers (PUM) in contrast negative unique markers (NUM), which are absent bands. These bands are used for genotype identification.

In the present study, fifty five amplified fragments were considered as unique markers. The highest number of species-specific marker was 15 markers generated with primer IS10, while the lowest number of species-specific marker was 8 markers generated with primer IS4 and IS6. On the other hand, the highest number of ISSR unique marker was scored for $F$. carica (8 markers) followed by $F$. retusa (7 markers), $F$. palmata (6 markers), $F$. elastica, $F$. platypoda, $F$. sycomorus (5 markers), $F$. deltoidea, $F$. infectoria, $F$. laurifolia, $F$. racemosa, $F$. religiosa, $F$. cordata and $F$. spragueana (2 markers), while the lowest number (1 marker) was scored for $F$. benjamina v. comosa, F. cunninghamii, F. macrophylla and F. mysorensis. Seventeen species out of nineteen species could be identified by the use of positive unique marker products. These markers ranged in size from 175 to $2403 \mathrm{bp}$. A total number of 55 unique markers were identified by all primers used in this investigation.

Ficus benjamina var. comosa, F. cunninghamii and F. macrophylla could be distinguished by the presence of one unique band IS4 $4_{1084 \mathrm{bp}}$, IS6 $6_{421 \mathrm{bp}}$ and IS3 $3_{1247 \mathrm{bp}}$, respectively. Eight species could be distinguished by the presence of two unique bands which were absent in all other species. Ficus deltoidea IS3699p and IS3 $3_{751 \mathrm{bp}}$, F. infectoria IS $_{236 \mathrm{bp}}$ and IS3 ${ }_{1003 \mathrm{bp}}, F$. laurifolia $\mathrm{IS}_{480 \mathrm{bp}}$ and IS3 $3_{849 \mathrm{bp}}, F$. mysorensis A9 ${ }_{745 \mathrm{bp}}$ and A9 ${ }_{1462 \mathrm{bp}}, F$. racemosa A9 193bp $_{\text {and }} \mathrm{IS6}_{201 \mathrm{bp}}, F$. religiosa $\mathrm{IS}_{1293 \mathrm{bp}}$ and $\mathrm{IS}_{1768 \mathrm{bp}}, F$. cordata IS10 $1842 \mathrm{bp}$ and IS10 ${ }_{2402 \mathrm{bp}}$ and finally $F$. spragueana IS3 $3_{21 \mathrm{bp}}$ and $\mathrm{A}_{216 \mathrm{bp}}$. 
POLYMORPHIC ANALYSIS AND GENETIC SIMILARITY OF GENUS ... 111

TABLE 5. Ficus species characterized by unique positive ISSR markers, marker size and total number of the marker identifying each species.

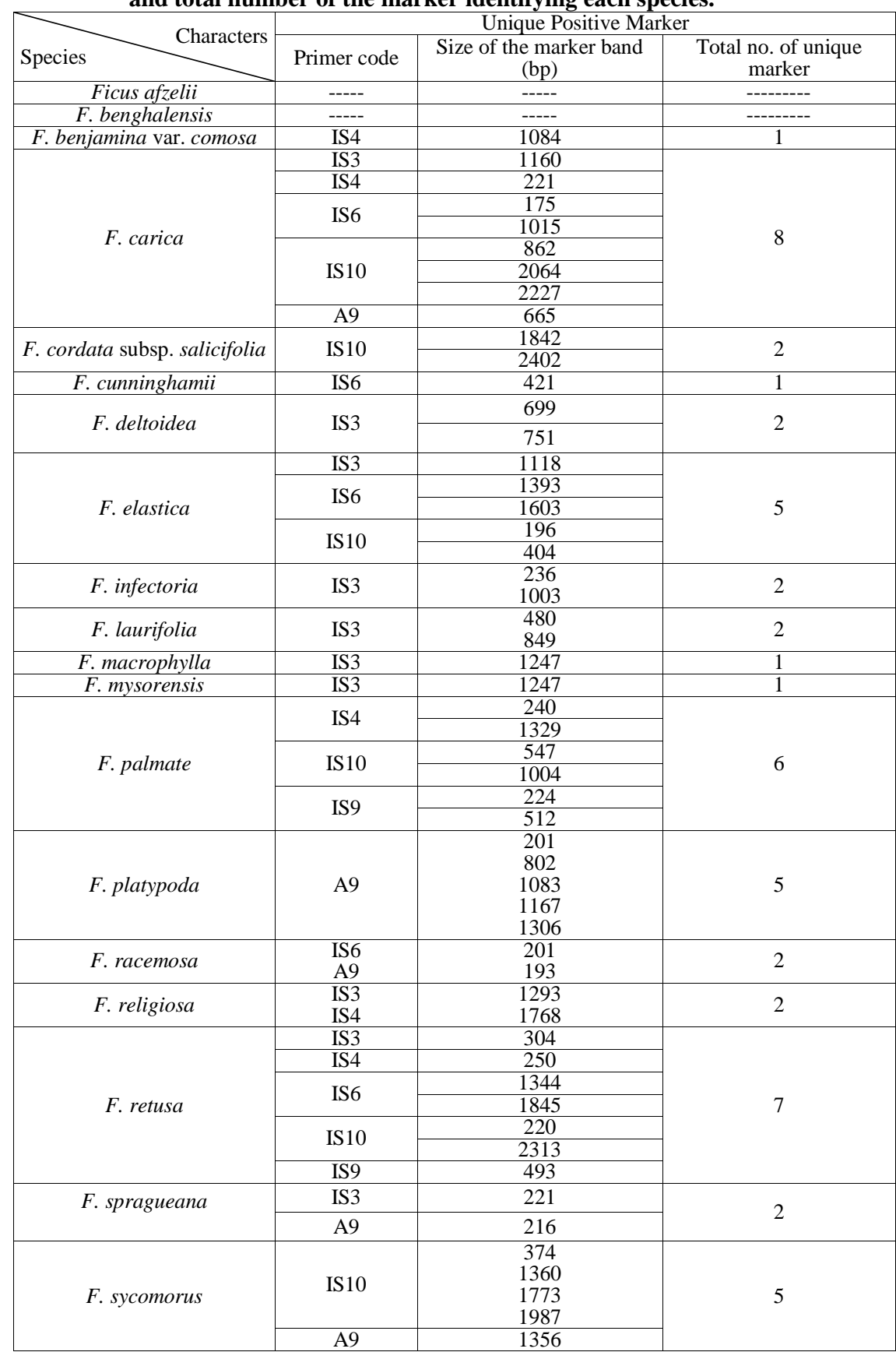

Egypt. J. Bot., 54, No. 1 (2014) 
Three species could be recognized by the presence of five unique bands. $F$. elastica IS3 $3_{1118 \mathrm{bp}}$, IS6 $6_{1393 \mathrm{bp}}$, IS6 $6_{1603 \mathrm{bp}}$, IS10 $1_{196 \mathrm{bp}}$ and IS10 $1_{404 \mathrm{bp}}, F$. platypoda $\mathrm{A} 9_{201 \mathrm{bp}}, \mathrm{A} 9_{802}, \mathrm{~A} 9_{1083 \mathrm{bp}}, \mathrm{A} 9_{1167 \mathrm{bp}}$ and $\mathrm{A} 9_{1306 \mathrm{bp}}$ and The last one was $F$. sycomorus A $9_{135 \mathrm{bp}}, \mathrm{IS} 10_{374 \mathrm{bp}}$, IS10 $1_{1360 \mathrm{bp}}$, IS10 $1773 \mathrm{bp}$ and IS10 $1987 \mathrm{bp}$. Ficus palmata was characterized by the presence of six unique bands IS4 $240 \mathrm{bp}$, IS4 $4_{1329 \mathrm{~b}}$, A9224bp, A $9_{512 \mathrm{bp}}$, IS10 $0_{547 \mathrm{bp}}$ and IS10 $1004 \mathrm{bp}$, whereas $F$. retusa was identified by the presence of seven unique bands IS3 $3_{304 \mathrm{bp}}$, IS4 $4_{250 \mathrm{bp}}$, IS6 $6_{1344 \mathrm{bp}}$, IS6 $_{1845 \mathrm{bp}}$, IS $_{10} 1_{220 \mathrm{bp}}$, IS10 ${ }_{2313 \mathrm{bp}}$ and A9493b. Ficus carica was identified by the highest number of unique marker. It was characterized by the presence of eight unique bands

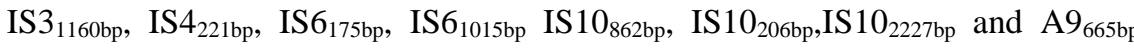
which were absent in all other species under the study. The remaining two species Ficus afzelii and F. benghalensis couldn't distinguished by any positive or negative unique marker. This study provides evidence that ISSR polymorphisms could be used as efficient tools for the detection of similarities, fingerprinting and phylogenetic relationships of the studied species. The same conclusion was obtained by Abdel-Tawab et al. (2001); Alexander et al. (2002); Arnau et al. (2003); Ghariani et al. (2003); Rajesh et al. (2003); Heikal et al. (2007) and Aparajita et al. (2008).

\section{Numerical analysis based on ISSR characters}

Matrix of similarity between pairs of individuals may be used as starting point for statistical procedures such as cluster analysis. In the cluster analysis, relatively homogenous groups of individuals cluster together in a hierarchical way and this clustering is visually displayed in a dendrogram. The denderogram is based on the information obtained from (Table 4) which has been used as a data matrix for measuring the genetic similarity among the examined taxa.

The UPGMA cluster analysis was carried out to represent graphically the genetic similarity among 19 taxa studied (Fig. 2). The dendrogram was separated into two main clusters; Cluster I included F. sycomorus (subgenus Sycomorus) which is split from the other species at 0.65 . Cluster II was divided into six groups: F. platypoda (subgenus Urostigma), F. retusa (subgenus Urostigma) and $F$. palmata (subgenus Sycomorus.) formed the first group in cluster II. $F$. platypoda showed 0.67 JSI with $F$. palmata and $F$. retusa in the group while $F$. palmata and $F$. retusa showed 0.71 JSI between them. The second group included F. carica (subgenus Ficus), F. cunninghamii (subgenus Urostigma) and F. benjamina var. comosa (subgenus Urostigma). F. carica showed 0.77 JSI with $F$. cunninghamii and $F$. benjamina v. comosa, while $F$. cunninghamii and $F$. benjamina var. comosa showed 0.80 JSI between them.Third group included F. mysorensis (subgenus Urostigma) and F. spragueana (subgenus Urostigma) 
at 0.72 JSI. Three species formed the fourth group in cluster II, in this group, $F$. cordata (subgenus Urostigma) showed 0.73 JSI with $F$. religiosa (subgenus Urostigma) and F. racemosa (subgenus Sycomorus) while $F$. religiosa and $F$. rasemosa showed 0.75 JSI between them. Fifth group showed 0.80 JSI between $F$. laurifoila (subgenus Urostigma) and $F$. infectoria (Subgenus Urostigma). The sixth group included five species, including $F$. macrophylla (Subgenus Urostigma) had 0.77 JSI with F. elastica (subgenus Urostigma) in the same group the two species had 0.81 JSI with $F$. deltoidea. $F$. deltoidea (subgenus Ficus) showed 0.81 JSI also with $F$. benghalensis (subgenus Urostigma) and F. afzelii (subgenus Urostigma). Ficus benghalensis and $F$. afzelii showed maximum similarity ( $0.85 \mathrm{JSI})$ between them indicated that these two species are closely related to each other.

The two studied taxa of subgenus Ficus viz F. carica and F. deltoidea were widely separated and didn't cluster together and showed relations with the taxa of subgenus Urostigma. Also, the three studied taxa of subgenus Sycomorus possessed relations with members of subgenus Urostigma.

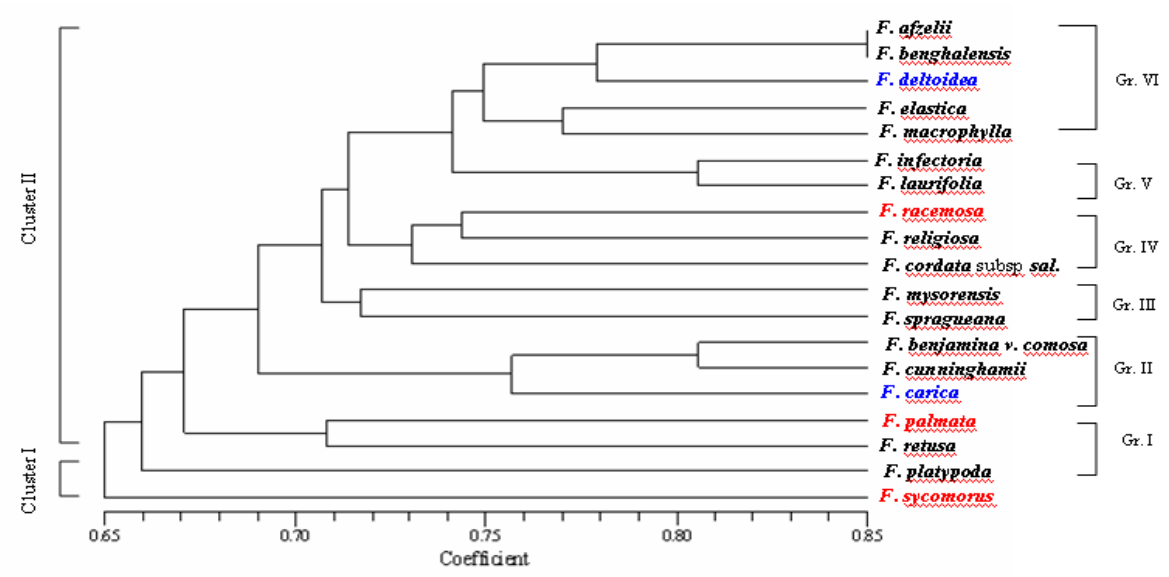

Fig. 2. UPGMA- dendrogram based on 229 ISSR characters illustrating genetic similarity between the studied taxa.

\section{Conclusions}

Although the genus as a whole represents a strictly monophyletic linkage, the study didn't support its traditional infrageneric classification by Corner (1965) based on syconium morphology. The studied taxa were distributed across the constructed phenograms, independent of the previous infrageneric classification of the genus. These results were in consistence with previous studies on the 
genus utilizing molecular criteria and reproductive biology (Rønsted et al., 2008). However, these studies showed clearly that the accepted infrageneric classification of the genus required a thorough revision by large number of primers and different techniques.

Acknowledgement: The authors are greatly indebted to (Late) Dr. Sayed F. Khalifa Professor of Plant Taxonomy and Flora, Ain Shams University, for suggesting, providing facilities and faithful.

\section{References}

Abdel-Tawab, F. M., Abo-Doma, A., Allam, A. I. and El-Rashedy, H. A. (2001) Assessment of genetic diversity for eight sweet sorghum cultivars (Sorghum bicolar L.) using RAPD analysis. Egypt. J. Genet. Cytol., 30, 41-50.

Adawy, S. S., Hussein, Ebtissam H. A., El-Khishin, Dina, Moharam, H. and ElItriby, Hanayia A. (2002)Genetic variability studies and molecular fingerprinting of some Egyptian date palm (Phoenix dactylifera L.) cultivars: II. RAPD and ISSR profiling. Arab J. Biotech., 5(2), 225-236.

Adawy, S. S., Hussein, Ebtissam H. A., Saker, M. M. and El-Itriby, Hanayia A. (2004a) Intera- and Inter-varietal variation of upper Egypt date palm cultivars (Phoenix dactylifera L.): I. As revealed by RAPD and ISSR markers. Proceed. Int. Conf. Genet. Eng. and Appl., Sharm El-Sheikh, South Sinai, Egypt (April, 8-11, 2004) 165-179.

Alexander, A. J. (2002) Genetic diversity of populations of Astragalus oniciformis using Inter- simple sequence repeat (ISSR) markers. M. Sc. Thesis. in Botany and Plant Pathology, Oregon State Univ., USA.

Aparajita, S., Senapati, S. K. and Rout, G. R. (2008) Identification and genetic relationships among nine Albizzia species based on morphological and molecular markers. Plant Biosystems., 142, 30-39.

Arnau, G., Lalemand, J. and Bouegoin, M. (2003) Fast and reliable strawberry cultivar identification using ISSR amplification. Euphytica., 129, 69-79.

Berg, C.C. and Corner, E. J. H. (2005) Moraceae - Ficus. Flora Malesiana Series I 17(2), 71 .

Blair, M. W., Panaud, O. and McCouch, S. R. (1999) Inter-simple sequence repeat (ISSR) amplification for analysis of microsatellite motif frequency and fingerprinting in rice (Oryza sativa L.). Theoretical and Applied Genetics, 98, 780-792.

Chatti, K., Salhi-Hannachi, A., Mars M, Marrakchi M and Trifi M. (2003) Genetic Diversity and phlogenic relationships in Tunisian fig (Ficus carica L.) cultivars mediated by RAPD. Biology, 2, 1- 4 .

Corner, E. J. H. (1965) Checklist of Ficus in Asia and Australasia with keys to identification. Gardens Bulletin Singapore, 21, 1-186.

Egypt. J. Bot., 54, No. 1 (2014) 
Danuta, R., Smolik, M. and Katarzyna, T. (2006) Genetic similarity of chosen Syringia species determined by the ISSR-PCR technique. Dendrobiology, 56, 61-67.

Dixon, D. J. (2001) Figs, wasps and species concepts: a revolution of the infraspecific taxa of Ficus macrophylla (Moraceae: Urostigma sect. Malvanthera). Austral. Syst. Bot., 14(1), 125-132.

Ghariani, S., Trifi-Farah, N., Chakroun, M., Marghali, S. and Marrakchi, M. (2003) Genetic diversity in Tunisian perennial rye grass revealed by ISSR markers. Genetic Resources and Crop Evolution, 50, 809-15.

Gillbert, J. E., Lewis, R. V., Wilkinson, M. J. and Caligari, P. D. S. (1999) Developing an appropriate strategy to assess genetic variability in plant germplasm collections. Theor. Appl. Genet., 98, 1125-1131.

Guasmi, F., Ferchichi, A., Farés, K. and Touil, L. (2006) Identification and differentiation of Ficus carica L. cultivars using inter simple sequence repeat markers. African J. Biotechnol., 5(15), 1370-1374.

GRIN (2008) Germplasm Resources Infprmation Network online Database USDA, ARS, National Resource Lab. Beltsuille, Maryland. http://www.ars gin.gov./var/apache/egebin/npgs/html/.

Frodin, D. G. (2004) History and concepts of fig plant genera. Taxon, 53, 753-776.

Ghariani, S., Trifi-Farah, N., Chakroun, M., Marghali, S. and Marrakchi, M. (2003) Genetic diversity in Tunisian perennial rye grass revealed by ISSR markers. Genetic Resources and Crop Evolution, 50, 809-15.

Guasmi, F., Ferchichi, A., Fares, K. and Touil, L. (2006) Identification and differentiation of Ficus carica L. cultivars using inter simple sequence repeat markers. African J. Biotechnology, 5(15), 1370-1374.

He, X., Liu, Q., Ishiki, K., Zhai, H. and Wang, Y. (2009) ISSR analysis of genetic diversity and relationships among sweet potato (Ipomoea batatas) landraces in China. PGR Newsletter, FAO-Biodiversity, 150, 35-41.

Heikal, A. Hadia, Hoda E. El-Mokadam and El-Tayeb, H. F. (2008) Phylogenetic relationship of four Ficus species using random amplified polymorphic DNA (RAPD) and inter simple sequence repeat (ISSR) markers. J. of Appl. Sci. Research, 4(5), 507514.

Heikal, A. Hadia, Mabrouk, Y., Badawy, O. M., El-Shehawy, A. and Effat A. Badr (2007) Fingerprinting Egyptian Gramineae Species Using Random Amplified Polymorphic DNA (RAPD) and Inter-simple Sequence Repeat (ISSR) Markers. $J$. Cell and Molecular Biology (RJCMB). 1(1), 15-22.

Hess, J., Kadereit, J. W. and Vargas, P. (2000) The colonization history of Olea europaea L. in Macaronesia based on internal transcribed spacer 1 (ITS-1) sequences, randomly amplified polymorphic DNAs (RAPD), and inter simple sequence repeats (ISSR). Mol. Ecol., 9, 857-68. 
Huang, J. C. and Sun, M. (2000) Genetic diversity and relationships of sweet potato and its wild relatives in Ipomoea series Batatas (Convolvulaceae) as revealed by intersimple sequence repeat (ISSR) and restriction analysis of chloroplast DNA. Theor. Appl. Gen., 100, 1050-1060.

IPNI (International Plant Names Index) (2008) Marck Jackson Application Manager Royal Botanic Gardens Kew. http://www.ipni.org/index.html.

Jaccard, P. (1908) Nouvelles recherches sur la distribution florale. Bulletin de la Societe Vaudoise des Sciences Naturelles, 44, 223-270.

Judd, W. S., Cambell, C. S., Kellogg, E. A. and Stevens, P. F. (1999) "Plant Systematics, a phylogenetic approach". Sinauer Associates. Inc. pp.72, 73, 290, 291, 302, 304.

Joshi, S. P., Gupta, V. S., Aggarwal, R. K., Ranjekar, P. K. and Brar, D. S. (2000) Genetic diversity and phylogenetic relationship as revealed by inter-simple sequence repeat (ISSR) polymorphism in the genus Oryza. Theoretical and Applied Genetics, 100, 1311-1320.

Kumar, L. D., Kathirvel, M., Rao, G. V. and Nagaraju, J. (2001) DNA profiling of disputed chilli samples (Capsicum annum) using ISSR-PCR and FISSR-PCR marker assays. Forensic Sci. Int. 116, 63-68.

Manimekalai, R. and Nagarajan, P. (2006) Assessing genetic relationships among coconut (Cocos nucifera $\mathrm{L}$.) accessions using inter simple sequence repeat markers. Scientia Horticulturae, 108, 49 - 54.

Martin, J. P. and Sanchez-Yelamo, M. D. (2000) Genetic relationships among species of the genus Diplotaxis (Brassicaceae) using inter simple sequence repeat markers. Theor. Appl. Genet, 101, 1234-1241.

McGregor, C. E., Lambert, C. A. and Greyling, M. M. (2000) Comparative assessment of DNA fingerprinting techniques (RAPD, ISSR, AFLP and SSR) in tetraploid potato (Solanum tuberosum L.) Euphytica, 35, 13-44.

Nabil Sabet A. M. and Abou-Ellail M. (2013) Genetic discrimination of Egyption fig cultivars reveaed by RAPD fingerprints. International Journal of Agricultural Research, 8 (1), 17-25.

Nagaoka, T. and Ogihara, Y. (1997) Applicability of inter-simple sequence repeat polymorphisms in wheat for use as DNA markers in comparison to RFLP and RAPD markers. Theoretical and Applied Genetics 94, 597-602.

Porebski, S., Bailey, L. G. and Baum, R. (1997) Modification of CTAB DNA extraction protocol for plants containing high polysaccharide and polyphenol components. Plant Mol. Biol. Reporter, 15(1), 8-15.

Prevost, A. and Wilkinson, M. J. (1999) A new system of comparing PCR primers applied to ISSR fingerprinting of potato cultivars. Theor. Appl. Genet., 98, 107-112. 
Rajesh, P. N., Sant, V.J. and Gupta, V. S. (2003) Genetic relationship among annual and perennial wild species of Cicer using ISSR polymorphism. Euphytica., 129, 1523.

Rohlf, F. J. (1998) NTSYS-pc. Numerical taxonomy and multivariate analysis system, version 2.02 Exeter Software, Setauket, New York, USA.

Rønsted, N., Weiblen, G. D., Savolainen, V. and Cook, J. M. (2008) Phylogeny, biogeography, and ecology of Ficus section Malvanthera (Moraceae). Molecular Phylogenetics and Evolution, 48, 12-22.

Rout G. and Aparajita S. (2009) Genetic Relationships among 23 Ficus Accessions Using Inter-Simple Sequence Repeat Markers J. Crop Sci. Biotech, 12 (2), 91 - 96.

Salhi-Hannachi A., Chatti, K., Mars M., Marrakchi M. and Trifi M. (2003) Comparative analysis of genetic diversity in two tunisian collections of fig cultivars based on random amplified polymorphic DNA and inter simple sequence repeats fingerprints. Genetic Resources and Crop Evolution, 13, 1-11.

Sneath, P. H. and Sokal, R. R. (1973) "Numerical Taxonomy Freeman", San Francisco. P. 573.

W $^{3}$ TROPICOS (Nomenclatural and Specimen Database of the Missouri Botenical Garden) (2008) http://www.mobot.org/w3t/search/vast.

Wagner, W. L., Herbst, D. R. and Sohmer, S. H. (1999) "Manual of the Flowering Plants of Hawai'I". 2 vol. Bishop Museum Special Publication 83, University of Hawai'i and Bishop Museum Press, Honolulu, HI.

Weiblen, G. D. (2000) Phylogenetic relationships of functionally dioecious Ficus (Moraceae) based on ribosomal DNA sequences and Morphology. American J. Bot. 87(9), 1342-1357.

Wolfe, A. D. and Liston, A. (1998b) Contributions of PCR-based methods to plant systematic and evolutionary biology. In: "Plant Molecular Systematics" II D. E. Soltis, P. S. Soltis and J. J. Doyle. Ed., pp. 43-86. Kluwer.

Wolfe, A. D., Xiang, Q. Y. and Kephart, S. R. (1998a) Diploid hybrid speciation in Penstemon (Scrophulariaceae). Proceedings of the National Academy of Sciences, USA. 95, 5112-5115.

Wolfe, A. D., Xiang, Q. Y. and Kephart, S. R. (1998b) Assessing hybridization in natural populations of Penstemon (Scrophulariaceae) using hyper-variable inter simple sequence repeat markers. Molecular Ecology, 7, 1107-1125.

(Received $1 / 10 / 2013$

accepted 16/12/2013) 


\title{
تحليل التباين والتماثل الوراثى لجنس فيكس (الفصيلة التوتيـة) فى

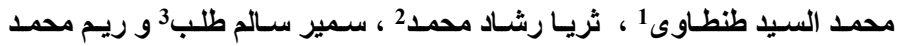 \\ صلاح الدين

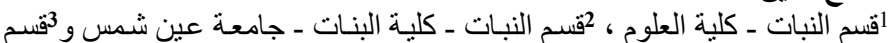

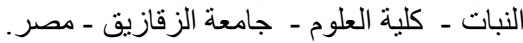

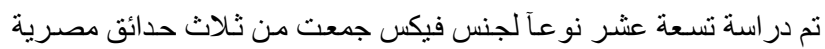

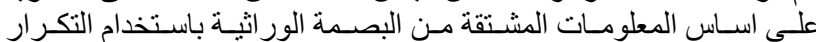

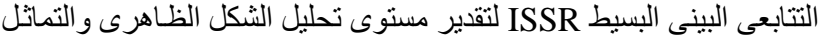

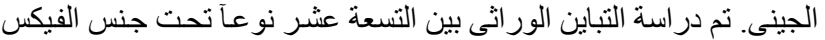

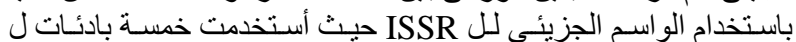
ISSR

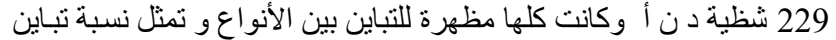

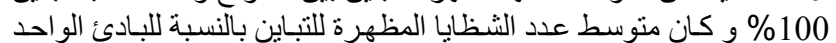

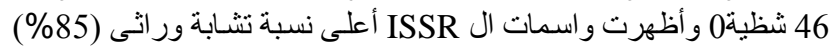

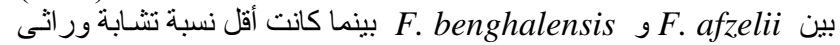

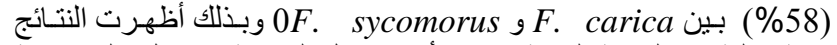

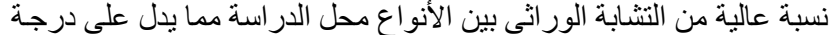

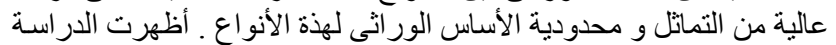

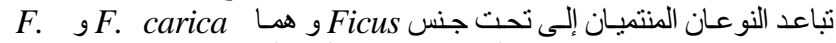
deltoidea

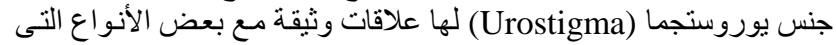

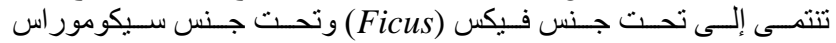

. (Sycomorus) 